\title{
Risk Assessment of Trace Metals in Roadsides Vernonia amygdalina Obtained in Abak, Nigeria
}

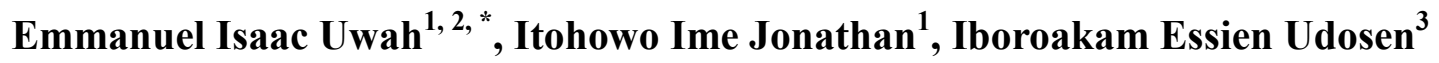 \\ ${ }^{1}$ Department of Chemistry, University of Uyo, Uyo, Nigeria \\ ${ }^{2}$ International Centre for Energy and Environmental Sustainability Research (ICEESR), University of Uyo, Uyo, Nigeria \\ ${ }^{3}$ Department of Zoology, Akwa Ibom State University, Ikot Akpaden, Akwa Ibom State, Nigeria \\ Email address: \\ emmanueliuwah@uniuyo.edu.ng (E. I. Uwah), aitychem@gmail.com (I. I. Jonathan), piccolosen@yaoo.com (I. E. Udosen) \\ ${ }^{*}$ Corresponding author
}

\section{To cite this article:}

Emmanuel Isaac Uwah, Itohowo Ime Jonathan, Iboroakam Essien Udosen. Risk Assessment of Trace Metals in Roadsides Vernonia amygdalina Obtained in Abak, Nigeria. Modern Chemistry. Vol. 8, No. 4, 2020, pp. 48-53. doi: 10.11648/j.mc.20200804.11

Received: February 23, 2020; Accepted: March 4, 2020; Published: December 31, 2020

\begin{abstract}
Levels of some trace metals $(\mathrm{Cu}, \mathrm{Zn}, \mathrm{Cd}, \mathrm{Pb}$ and $\mathrm{Mn})$ were investigated in roadside soil and the leaves of a common perennial vegetable (Vernonia amygdalina). Soil and vegetable samples were collected from roadsides of three major roads in Abak (Ikot Ekpene road, Ikot Abasi road and Uyo road). The samples were digested using standard methods and analysed using Unicam 939/959 atomic absorption spectrophotometer. The results revealed that the levels of all the metals in soil samples were higher than the levels of metals in the corresponding vegetable. The metal levels in both the soil and vegetable samples were in the order: $\mathrm{Cu}>\mathrm{Zn}>\mathrm{Pb}>\mathrm{Mn}>\mathrm{Cd}$. Cu, $\mathrm{Cd}$ and $\mathrm{Pb}$ with the levels of 106.71, 0.25 and $0.54 \mathrm{mg} / \mathrm{kg}$, respectively, in plant samples respectively were higher than the WHO maximum permissible limits of $73.30 \mathrm{mg} / \mathrm{kg}$ for Cu ; $0.20 \mathrm{mg} / \mathrm{kg}$ for $\mathrm{Cd}$ and $0.30 \mathrm{mg} / \mathrm{kg}$ for $\mathrm{Pb} . \mathrm{Zn}(45.25 \mathrm{mg} / \mathrm{kg})$ and $\mathrm{Mn}(0.47 \mathrm{mg} / \mathrm{kg})$ were below the maximum permissible limits of $99.40 \mathrm{mg} / \mathrm{kg}$ for $\mathrm{Zn}$ and $500 \mathrm{mg} / \mathrm{kg}$ for Mn. Further analysis of the $V$. amygdalina pollution status using transfer factor (TF) revealed that $\mathrm{Zn}$ had the highest TF value of 0.5 while $\mathrm{Cd}$ recorded the lowest of 0.019 . The toxic risk (hazard quotient) for adults and children consuming the $V$. amygdalina leaves showed that $\mathrm{Cu}$ was greater than one (1) and other metals were generally low and within safe limits. The Hazard indices were greater than 1 for both adults $(1.69 \mathrm{E}+0)$ and children $(1.94 \mathrm{E}+0)$. This implies that the trace metal contamination was capable of posing health hazard to consumers of this plant.
\end{abstract}

Keywords: Risk, Assessment, Trace Metals, Contamination, Vernonia amygdalina, Roadsides

\section{Introduction}

The herb known as bitter leaf (Vernonia amygdalina) is a shrub or small tree that can reach 23 feet in height when fully grown. Bitter leaf has a grey or brown coloured bark, which has a rough texture and is flaked. The herb is an indigenous African plant; which grows in most parts of sub-Saharan Africa. It is a medicinal plant and fresh bitter leaf is of great importance in human diet because of the presence of vitamins and mineral salts [1]. It is a very important protective food and useful for the maintenance of health, prevention and treatment of various diseases. Some principal chemical constituents found in bitter leaf are a class of compounds called steroid glycosides- type vernonioside B1 these chemical substances possess a potent anti-parasitic, anti-tumor, and bactericidal effects. Bitter leaf is mainly employed as an agent in treating schistsomiasis, which is a disease caused by parasitic worms. It is also useful in the treatment of diarrhea and general physical malaise. Bitter leaf helps to cleanse vital organs of the body like the liver and the kidney, and is used in the treatment of skin infections such as ringworm, rashes and eczema. However, bitter leaf and other vegetables contain both essential and toxic metals over a wide range of concentrations [2].

Heavy or toxic metals are trace metals which are detrimental to human health and having a density of at least five times that of water. Large quantities of pollutants such as trace metals have continuously been introduced into the ecosystems as a result of urbanization and industrial processes [3]. Once liberated into the environment through the air, drinking water, food, or countless varieties of man- 
made chemicals and products, trace metals are taken into the body via inhalation, ingestion and skin absorption. If trace metals enter and accumulate in body tissues faster than the body's detoxification pathways can dispose of, then a gradual build-up of these toxins occurs. High concentration exposure is not a necessity to produce a state of toxicity in the body, as trace metal accumulation occurs in body tissues gradually and, over time, can reach toxic concentration levels, much beyond the permissible limits [4]. Higher levels of even the essential metals may lead to toxicity [5].

Trace metal contamination is a major problem of the environment (biosphere) especially of growing medium sized cities in developing countries primarily due to uncontrolled pollution levels driven by causative factors like industrial growth and heavy increase in traffic using petroleum fuels. Trace metal contamination may occur due to factors including irrigation with contaminated water, the addition of fertilizers and metal based pesticides, industrial emissions, transportation, harvesting process, storage and/or sale [2, 6].

Atmospheric depositions are captured by the plant canopy and accumulated in or on the leaves. As the accumulation is roughly a function of the deposited amount of pollutants, the exposure time and the effects of climatic factors are of prime importance. As such, many plant species are useful for biomonitoring atmospheric deposition of pollutants. In the case of trace metal containing aerosols, the elements are mainly accumulated on the leaf surface. Trace metal pollution not only affects the production and quality of crops, but also influences the quality of the atmosphere and water bodies, and threatens the health and life of animals and humans within a food chain. Most severely is that this kind of pollution is covert, long term and non-reversible [7]. Trace metals are also one of the major contaminating agents in our food supply [8,9]. Vegetables are vital to the human diet and in particular provide the well-known trace elements and trace metals. Minor or trace elements are essential for good health if they come from an organic or plant source [10]. In contrast, if they come from an inorganic or metallic source, they become toxic. The processes of plant growth depend on the cycle of nutrients including trace elements, from soil to plant [11]. Vegetables, especially the leafy ones, accumulate higher amounts of trace metals because they absorb these metals in their leaves.

Food safety is a major concern at present. The increasing demand of food safety has accelerated research regarding the risk associated with food consumption contaminated by trace metals [12]. The rate at which trace metals are accumulated in the soil depends on the physicochemical properties of the soil and the relative efficiency of crops to remove the metals from the soil. Trace metals accumulated in cultivated soils can be transferred to humans through various exposure pathways causing adverse effects on human health [13].

Different vegetables are cultivated on the roadsides of major roads in Abak. These vegetables are exposed to trace metal contaminations as a result of atmospheric deposition due to anthropogenic activities like vehicular emission, industrial emission and burning of all forms of wastes along the roadsides. These are in addition to the plants uptake from the soil, as a result of the agricultural practices adopted by the farmers to increase productivity. This study was conducted to quantify the levels of some trace metals in leaves of a common perennial vegetable ( $V$. amygdalina $)$ grown along the roadsides of three major roads in Abak and to assess the health risks associated with the consumption of the vegetable.

\section{Materials and Methods}

\subsection{Study Area}

The study was carried out in Abak, Akwa Ibom State, Nigeria. The area lies between latitudes $4^{\circ} 59^{\prime} \mathrm{N}$ and $4^{\circ} 9833^{\prime} \mathrm{N}$ and longitudes $7^{\circ} 47^{\prime} \mathrm{E}$ and $7^{\circ} 783^{\prime} \mathrm{E}$ with an area of $190 \mathrm{~km}^{2}$ $\left(70 \mathrm{~m}^{2}\right)$. The major occupation of the people is farming. There are also automobile mechanics, welders, petty traders, timber dealers, as well as production industries like paint and fertilizer blending.

\subsection{Sample Collection}

Leaves samples of roadsides $V$. amygdalina grown along three major roads (Abak/Ikot Ekpene, Abak/Ikot Abasi and Abak/Uyo) in Abak were collected. Samples were randomly collected at a height of $10 \mathrm{~cm}$ above the soil surface with the help of a stainless knife and pooled together to obtain composite samples for each road. Corresponding composite soil samples were also collected in the area, as described by [14]. The vegetable and soil samples were equally collected at Ikot Ekang village, about $10 \mathrm{~km}$ from the study area. The collected samples were kept in clean polyethylene bags, properly labeled and transported to the laboratory.

\subsection{Sample Pretreatment and Preparation}

The vegetable samples were washed with clean tap water according to the normal household technique. After draining the excess water, the samples were chopped into small pieces and oven dried at $50-60^{\circ} \mathrm{C}$, ground into powder. Exactly 1.0 $\mathrm{g}$ was weighed into a crucible and ashed in a SXL muffle furnace at a temperature range of $750^{\circ} \mathrm{C}-850^{\circ} \mathrm{C}$ for 4 hours. The crucible with the ash was removed from the furnace and allowed to cool. The ash was leached with $5 \mathrm{~cm}^{3}$ of $6 \mathrm{M} \mathrm{HCl}$ and transferred into a $50 \mathrm{~cm}^{3}$ volumetric flask. The volume was made up to $50 \mathrm{~cm}^{3}$ with distilled water. The solution was stored in a plastic reagent bottle for trace metal analyses.

The soil samples were air-dried for 48 hours, ground and homogenised. The homogenised matrix was sieved using a 2 $\mathrm{mm}$ mesh sieve. Two (2) $\mathrm{g}$ of the ground soil were digested with $15 \mathrm{~cm}^{3}$ aqua regia $\left(2 \mathrm{HNO}_{3}: 1 \mathrm{HClO}_{4}\right)$ and heated to near dryness, leached with $5 \mathrm{~cm}^{3}$ of $20 \% \mathrm{HNO}_{3}$. The solutions were filtered into acid-washed $100 \mathrm{~cm}^{3}$ volumetric flask after being rinsed with deionised water. Further, the solution was made up to $50 \mathrm{~cm}^{3}$ with deionised water prior to trace metal analysis. 


\subsection{Instrumental Analysis}

Trace metals $(\mathrm{Cu}, \mathrm{Zn}, \mathrm{Cd}, \mathrm{Pb}$, and $\mathrm{Mn})$ in soil and plant samples were determined as described by [15] using atomic absorption spectrophotometer (AAS) (UNICAM939/959 model). The sample solutions were aspirated into the instrument and the absorbance obtained was used to determine the concentrations of the metals in the different samples from calibration curves.

\subsection{Transfer Factor (TF)}

The transfer factor (TF) of metals from soil to vegetables was calculated using Equation 1 described by [16].

$$
T F=\frac{C_{\text {plant }}}{C_{\text {soil }}}
$$

Where, $C_{\text {plant }}$ and $C_{\text {soil }}$ represent the levels of the toxic metal in the plant and soil, respectively.

\subsection{Health Risk Assessment}

For the assessment of health risks through consumption of the roadsides Vernonia amygdalina leaves, the daily intake of metal (DIM), hazard quotient (HQ), and the hazard index (HI) were evaluated.

\subsubsection{Daily Intake of Metals (DIM)}

Toxic trace metals enter the human body through different path-ways. It may be oral intake (through consumption foods), inhalation, and or dermal contact [17]. Equation 2 was used to evaluate the daily intake of metals in the human body.

$$
D I M=\frac{\left(C_{\text {metal }} \times C_{\text {factor }} \times D_{\text {food }}\right)}{B_{\text {average weight }}}
$$

Where $C_{\text {metal }}, C_{\text {factor }}, D_{\text {food }}$ and $B_{\text {average weight }}$ represent the trace metal level $(\mathrm{mg} / \mathrm{kg})$ in plants, conversion factor, and daily intake of vegetable by human and average body weight, respectively [18]. Fresh green vegetable weight was converted to dry weight by using the conversion factor 0.085 as described by [19 - 21]. The average daily vegetable intakes were taken as 0.345 and $0.232 \mathrm{~kg} /$ person/day for adults and children, respectively, while the average body weights were taken as 55.9 and $32.7 \mathrm{~kg}$ for adults and children, respectively 18,22$]$. The health risk for adults and children are considered separately since the contact pathway with each exposure way changes with age.

\subsubsection{Risk Characterisation}

The health risks associated with metals ingested through vegetable consumption was assessed using hazard quotient (HQ) as expressed in equation 3 as modified by [23].

$$
H Q=\frac{D I M}{R f d}
$$

Where DIM is the daily intake of metals $\left(\mathrm{kg} \mathrm{person}^{-1}\right.$ day $\left.^{-1}\right)$ through vegetable consumption and $R f d$ represents reference oral dose $\left(\mathrm{mg} \mathrm{kg}^{-1} \mathrm{day}^{-1}\right)$. The $R f d$ value for $\mathrm{Cu}, \mathrm{Pb}, \mathrm{Cd}, \mathrm{Mn}$, and $\mathrm{Zn}$ are $0.04,0.004,0.001,0.033$, and $0.30\left(\mathrm{mg} \mathrm{kg}^{-1} \mathrm{bw}\right.$ day $\left.^{-1}\right)$, respectively [24]. The $R f d$ is an estimation of the daily exposure to which the human population is likely to be without any appreciable risk of deleterious effects during a lifetime. The exposed population is assumed to be safe when HQ is $<1$ [18].

In a situation where there are toxicants or multiple exposure routes, it will be best that their possible interactions are taken into consideration [19]. It is assumed that the toxic risk due to potentially hazardous chemicals in the same medium is cumulative; therefore, the summation of the HQs was done to obtain the overall toxic risk; the hazard index (HI) is shown in Equation 4 according to [19 and 25].

$$
H I=\sum H Q i ; i=1 \ldots . \mathrm{n}
$$

Where $\mathrm{n}$ is the number of trace metals. This computation was done to determine the level of risk posted. If the calculated $\mathrm{HI}$ is greater than one, then the toxic adverse effect due to the exposure pathway or toxicant will be assumed to be hazardous and negligible when $\mathrm{HI}$ is less than one.

\subsection{Statistical Analysis}

Statistical analysis of data was carried out using Microsoft Excel 2007 and the SPSS 16.0 statistical package program.

\section{Results and Discussion}

\subsection{Levels and Distribution of Trace Metals in Soil and Vegetable Samples}

The levels of the investigated trace metals in soil and plant samples are presented in Tables 1 and 2, respectively. Generally, the values of all the metals in soil and plant were higher in the study sites than in the control site and the levels of the metals in soil samples were higher than those in plant for all the sites. The results agreed with the report of [26]. The metal levels in the soil samples were significantly higher in samples from Ikot Abasi Road and lower in samples from Ikot Ekpene Road. The metal levels in the soil were in the order: $\mathrm{Cu}>\mathrm{Zn}>\mathrm{Pb}>\mathrm{Mn}>\mathrm{Cd}$. The only exception is that $\mathrm{Cd}(31.56 \mathrm{mg} / \mathrm{kg})$ was higher than $\mathrm{Mn}(27.94 \mathrm{mg} / \mathrm{kg})$ in soil from Ikot Abasi Road. The metal levels in the vegetable samples were also in the order: $\mathrm{Cu}>\mathrm{Zn}>\mathrm{Pb}>\mathrm{Mn}>\mathrm{Cd}$. This could be attributed to different anthropogenic activities that affect the availability, mobility of metals and physicochemical parameters. The levels of $\mathrm{Cu}$ and $\mathrm{Pb}$ obtained in the vegetable in this study were higher than the FAO/WHO maximum permissible levels of 73.30 and 0.3 for $\mathrm{Cu}$ and $\mathrm{Pb}$, respectively in the vegetable as provided by [27 and 28]. Those of $\mathrm{Zn}$ and $\mathrm{Mn}$ lower than the FAO/WHO maximum permissible levels of 99.40 and $500 \mathrm{mg} / \mathrm{kg}$ in the vegetable as provided by [27 and 28]. Cd levels were lower than the $0.2 \mathrm{mg} / \mathrm{kg}$ provided by [27 and 28] except for the vegetable samples from Abak/Ikot Abasi Road and Abak/Uyo Road whose Cd levels were $0.32 \pm 0.002$ and 0.34 $\pm 0.004 \mathrm{mg} / \mathrm{kg}$, respectively. 
Table 1. Level ( $\mathrm{mg} / \mathrm{kg})$ of trace metals in soil samples.

\begin{tabular}{llllll}
\hline Sites & Cu & Zn & Cd & Pb & Mn \\
\hline AIE & $243.78 \pm 0.02$ & $104.26 \pm 0.10$ & $16.45 \pm 0.03$ & $46.07 \pm 0.02$ & $31.56 \pm 0.02$ \\
AIA & $360.30 \pm 0.02$ & $161.94 \pm 0.04$ & $38.02 \pm 0.03$ & $60.22 \pm 0.03$ & $27.94 \pm 0.02$ \\
AU & $254.47 \pm 0.002$ & $156.84 \pm 0.02$ & $23.63 \pm 0.01$ & $50.08 \pm 0.03$ & $29.29 \pm 0.02$ \\
CTS & $185.53 \pm 0.04$ & $92.30 \pm 0.10$ & $0.51 \pm 0.21$ & $18.38 \pm 0.21$ & $19.50 \pm 0.03$ \\
\hline
\end{tabular}

AIE $=$ Abak/Ikot Ekpene Road, AIA $=$ Abak/Ikot Abasi Road, AU = Abak/Uyo Road, CTS $=$ Control Sample

The high levels of $\mathrm{Cu}$ recorded in both soil and the plant samples in this study, could be attributed to the discharge of domestic waste, wind-blown dust, decaying vegetation and forest fire [5]. The fact that $\mathrm{Pb}$ and $\mathrm{Cd}$ are traffic-related metals that originated mainly from the combustion of leaded fuel, lubricating motor oil, vehicle tire wear, and brake pads, makes it possible to also link their levels on the roadside plants from the fumes emitted by the automobile plying the high ways [29].

Table 2. Levels (mg/kg) trace metals in Vernonia amygdalina leaves samples.

\begin{tabular}{|c|c|c|c|c|c|}
\hline Site & $\mathbf{C u}$ & Zn & Cd & $\mathbf{P b}$ & Mn \\
\hline AIE & $100.93 \pm 0.004$ & $48.37 \pm 0.002$ & $0.08 \pm 0.001$ & $0.56 \pm 0.005$ & $0.44 \pm 0.000$ \\
\hline AIA & $116.76 \pm 0.004$ & $61.14 \pm 0.002$ & $0.32 \pm 0.002$ & $0.52 \pm 0.001$ & $0.54 \pm 0.002$ \\
\hline $\mathrm{AU}$ & $102.44 \pm 0.009$ & $31.25 \pm 0.003$ & $0.34 \pm 0.004$ & $0.55 \pm 0.000$ & $0.43 \pm 0.000$ \\
\hline
\end{tabular}

$\mathrm{AIE}=$ Abak/Ikot Ekpene Road, AIA = Abak/Ikot Abasi Road, AU = Abak/Uyo Road, CTS = Control Sample,

$\mathrm{BDL}=$ Below Detection Limit.

High $\mathrm{Cu}$ levels in the soil could reduce the uptake of $\mathrm{Mn}$ to below adequate level for plant [30]. High $\mathrm{Cu}$ levels in the soil could also be attributed to high Iron (Fe) and molybdenum (Mo) fertilizer applications [31].

\subsection{Transfer Factor (TF) of Trace Metals}

The calculated TF of trace metals from soil to the $V$. amygdalina are as presented in Table 3.

Table 3. Transfer factor (TF) of trace metals from soil to $V$. amygdalina.

\begin{tabular}{|c|c|c|c|c|c|}
\hline \multirow{2}{*}{ Site } & \multicolumn{5}{|c|}{ Trace metals } \\
\hline & $\mathrm{Cu}$ & Zn & Cd & $\mathbf{P b}$ & Mn \\
\hline AIE & 0.500 & 0.710 & 0.015 & 0.010 & 0.017 \\
\hline AIA & 0.360 & 0.450 & 0.024 & 0.040 & 0.031 \\
\hline $\mathrm{AU}$ & 0.580 & 0.350 & 0.019 & 0.080 & 0.026 \\
\hline
\end{tabular}

$\mathrm{AIE}=\mathrm{Abak} / \mathrm{Ik}$ t Ekpene Road, AIA $=$ Abak/Ikot Abasi Road, AU = Abak/Uyo Road

From the trace meals $(\mathrm{Cu}, \mathrm{Zn}, \mathrm{Cd}, \mathrm{Pb}$ and $\mathrm{Mn})$ studied, the highest TF was recorded by $\mathrm{Zn}(0.500)$ while the lowest was recorded by $\mathrm{Cd}(0.019)$. The higher the TF values, the more mobile and available the metals are in the soil [18]. As the level of trace metals in the soil increased, the plant uptake also increased. The results recorded in this study, was in agreement with findings by [32 and 33]. Soil-to-plant transfer is one of the key processes of human exposure to toxic metals through food chain, and it reveal bioavailability of trace metals in investigated soils.

\subsection{Risk Assessment}

The estimated daily intake of metals (DIM) for ingestion of $V$. amygdalina obtained for adults and children. The results revealed that intake values for trace metals via the consumption of the investigated vegetable collected from the studied sites were of the trend: $\mathrm{Cu}>\mathrm{Zn}>\mathrm{Pb}>\mathrm{Cd}>\mathrm{Mn}$ for both adults and children. The values from Table 4 revealed that $\mathrm{Cu}$ contributed most to the dietary intake of trace metals through consumption of bitter leaf while Mn contributed least for all the three roadsides in the area. The result also indicate that the metal intake for children were higher than those for adults.

Table 4. Estimated daily intake of metals (DIM) via consumption of V. amygdalina.

\begin{tabular}{|c|c|c|c|c|c|c|}
\hline \multirow{2}{*}{ Location } & \multicolumn{6}{|c|}{ Trace Metals } \\
\hline & $\mathrm{Cu}$ & Zn & Cd & $\mathbf{P b}$ & Mn & CDI \\
\hline \multicolumn{7}{|l|}{ Adults } \\
\hline AIE & $5.28 \mathrm{E}-02$ & $2.53 \mathrm{E}-02$ & 4.19E-05 & $2.93 \mathrm{E}-04$ & $2.31 \mathrm{E}-04$ & $7.88 \mathrm{E}-02$ \\
\hline AIA & $6.12 \mathrm{E}-02$ & $3.20 \mathrm{E}-02$ & $1.68 \mathrm{E}-04$ & 2.72E-04 & 2.83E-04 & $9.39 \mathrm{E}-02$ \\
\hline $\mathrm{AU}$ & $5.36 \mathrm{E}-02$ & $1.64 \mathrm{E}-02$ & $1.18 \mathrm{E}-04$ & $2.88 \mathrm{E}-04$ & $2.25 \mathrm{E}-04$ & 7.07E-02 \\
\hline \multicolumn{7}{|l|}{ Children } \\
\hline AIE & $6.09 \mathrm{E}-02$ & 2.92E-02 & $4.82 \mathrm{E}-05$ & $3.38 \mathrm{E}-04$ & $2.65 \mathrm{E}-04$ & $9.07 \mathrm{E}-02$ \\
\hline AIA & 7.04E-02 & 3.69E-02 & $1.93 \mathrm{E}-04$ & $3.14 \mathrm{E}-04$ & $3.26 \mathrm{E}-04$ & $1.08 \mathrm{E}-01$ \\
\hline UA & $6.18 \mathrm{E}-02$ & $1.88 \mathrm{E}-02$ & $2.05 \mathrm{E}-04$ & $3.32 \mathrm{E}-04$ & $2.59 \mathrm{E}-04$ & $8.14 \mathrm{E}-02$ \\
\hline
\end{tabular}

$\mathrm{AIE}=$ Abak/Ikot Ekpene Road, AIA = Abak/Ikot Abasi Road, AU = Abak/Uyo Road, CDI = Cumulative daily Intake 


\subsection{Evaluation of Toxic Risk}

The hazard quotient (HQ) and hazard index (HI) helps in the evaluation of the magnitude of harm posed to the consumers of $V$. amygdalina contaminated with trace metals. The result summarized in Table 5 showed that the HQ of $\mathrm{Cu}$ was all greater than one (1) while other metals $(\mathrm{Zn}, \mathrm{Cd}, \mathrm{Pb}$ and $\mathrm{Mn}$ ) were less than one (1). As noted by [34 and 5], this suggests significant risk to the consumers of the vegetable as a result of the high level of $\mathrm{Cu}$.

The summation of the HQs gave the overall toxic risk, which is the hazard index (Table 5). From the general observation, all the computed $\mathrm{HI}$ values were above unity for both adults and children. This indicates that the consumers of $V$. amygdalina plant from the roadsides of these major roads are at potential health risks.

Table 5. Estimated hazard quotients (HQ) and hazard index (HI) for adults and children due to daily intake of metals in V. amygdalina.

\begin{tabular}{lllllll}
\hline \multirow{2}{*}{ Location } & HQ & & & & & Mn \\
\cline { 2 - 7 } & $\mathbf{C u}$ & $\mathbf{Z n}$ & $\mathbf{C d}$ & $\mathbf{P b}$ & HI \\
\hline Adults & & & & & & \\
AIE & $1.32 \mathrm{E}+00$ & $8.45 \mathrm{E}-02$ & $4.19 \mathrm{E}-02$ & $7.34 \mathrm{E}-02$ & $6.99 \mathrm{E}-03$ & $1.53 \mathrm{E}+00$ \\
AIA & $1.53 \mathrm{E}+00$ & $1.07 \mathrm{E}-01$ & $1.68 \mathrm{E}-01$ & $6.81 \mathrm{E}-02$ & $8.58 \mathrm{E}-03$ & $1.88 \mathrm{E}+00$ \\
AU & $1.34 \mathrm{E}+00$ & $5.46 \mathrm{E}-02$ & $1.78 \mathrm{E}-01$ & $7.21 \mathrm{E}-02$ & $6.83 \mathrm{E}-03$ & $1.65 \mathrm{E}+00$ \\
Children & & & & & & \\
AIE & $1.52 \mathrm{E}+00$ & $9.72 \mathrm{E}-02$ & $4.82 \mathrm{E}-02$ & $8.44 \mathrm{E}-02$ & $8.04 \mathrm{E}-03$ & $1.76 \mathrm{E}+00$ \\
AIA & $1.76 \mathrm{E}+00$ & $1.23 \mathrm{E}-01$ & $1.93 \mathrm{E}-01$ & $7.84 \mathrm{E}-02$ & $9.87 \mathrm{E}-03$ & $2.16 \mathrm{E}+00$ \\
AU & $1.54 \mathrm{E}+00$ & $6.28 \mathrm{E}-02$ & $2.05 \mathrm{E}-01$ & $8.29 \mathrm{E}-02$ & $7.86 \mathrm{E}-03$ & $1.90 \mathrm{E}+00$ \\
\hline
\end{tabular}

$\mathrm{AIE}=$ Abak/Ikot Ekpene Road, AIA = Abak/Ikot Abasi Road, AU = Abak/Uyo Road,

\section{Conclusion}

Based on the analyses and results, it was concluded that the roadsides soil and vegetable ( $V$. amygdalina) samples contain variable levels of the investigated trace metals. The levels of these metals were lower in the control samples than samples from the study area. The contamination sources could be linked to the anthropogenic activities like indiscriminate dumping of domestic wastes, metallic waste, used lubricating oil spillage and combustion of fuel as well as wearing of vehicular tires and brake pads and all kinds of agricultural activities in the area. The health risk assessment indicated that the hazard quotient (HQ) for $\mathrm{Cu}$ was all greater than one (1) which suggests significant risk to the consumers of the vegetable as a result of the high level of $\mathrm{Cu}$, while those of $\mathrm{Zn}, \mathrm{Cd}, \mathrm{Pb}$ and $\mathrm{Mn}$ were less than one (1). The computed hazard index (HI) values were above unity for both adults and children, indicating that the consumers of $V$. amygdalina from the roadsides of these major roads are at potential health risks. Further research should be carried out on remediation of trace metals in the roadsides soil of the study area to reduce their bioaccumulation in plants and possible health risk associated with their consumption.

\section{References}

[1] Sobukola, O. P. and Dairo, O. U. (2007). Modeling drying kinetics of fever leaves (Ocimum viride) in a convective hot air dryer, Niger Food Journal, 25 (1): 145-153.

[2] Radwan, M. A. and Salama, A. K. (2006). Market basket survey for some heavy metals in Egyptian fruits and vegetables. Food Chemistry and Toxicology, 44: 12731278 .

[3] Udosen, E. D., Uwah, E. I. and Jonathan, I. I. (2017). Levels of Trace Metals in Washed and Unwashed leaves of Roadsides Vernonia amygdalina Obtained in Abak, Akwalbom State, Nigeria. International Journal of Advances in Pharmacy, Biology and Chemistry (IJAPBC), 6 (2): 1-8.

[4] Suruchi, Singh; Mandana, B., Russly, A. R., Farah, S. T., Noranizan, M. A., Zaidul, I. S. and Ali, G. (2012). Antioxidant activity of winter melon (Benincasa hispida) seeds using conventional soxhlet extraction technique, International Food Research Journal, 19 (1): 229-234.

[5] Udosen, E. D. (2015). Concepts in Environmental Chemistry, Anikzo Global Ventures, pp. 156-171.

[6] Duran, A., Tuzen M. and Soylak M. (2007). Trace element levels in some dried fruit samples from Turkey. International Journal of Food Science and Nutrition, 59: 581-589.

[7] Zhang, N. (1999). Advance of the research on heavy metals in soil plant system. Advance in environmental science, 7 (4): 30-33.

[8] Zaidi, M. I., Asrar. A., Mansoor, A. and Farooqui, M. A. (2005). The heavy metals concentration along roadside trees of Quetta and its effects on public health. Journal of Applied Sciences, 5 (4): 708-711.

[9] Khair, M. H. (2009). Toxicity and accumulation of copper in Nannochloropsisoculata (Eustigmatophycea, Heterokonta). World Applied Sciences Journal, 6 (3): 378-384.

[10] Todd, G. P. (1980). Nutrition, health and diseases. The Institution of nutritional science journal, 6: 1-12.

[11] Mohamed, A. E., Rashed, M. N. and Mofty, A. (2003). Assessment of essential and toxic elements in some kinds of vegetables. Ecotoxicology and Environmental safety, 55: 251260 .

[12] Mansour, S. A., Belal, M. H., Abou-Arab, A. A. K., and Gad M. F. (2009). Monitoring of pesticides and heavy metals in cucumber fruits produced from different farming systems. Chemosphere, 75: 601-609. 
[13] Qishlaqi, A., Moore F. and Forghani G. (2008). Impact of untreated wastewater irrigation on soils and crops in Shiraz sub urban area, SW Iran. Environmental Monitoring and Assessment 141: 257-273.

[14] Chimuka, L., Mugwedi, R., Moboladisoro, B. H. and Odiyo, O. J. (2005). Metals in environmental media: A study of trace and platinum group metals in Thohoyandou, South Africa. Water SA, 31 (4): 581-588.

[15] AOAC (Association of Analytical Chemists) (2010). Official method of analysis (18 ${ }^{\text {th }}$ edn) Washington, D. C: pp. 200-381.

[16] Lokeshwari, H., and Chandrappa, G. T. (2006). Impact of heavy metal contamination of Bellandur lake on soil and cultivated vegetation. Current Science, 91 (5), pp. 622-27.

[17] Shahid, N., Zia, Z., Shahid, M., Fraiq Bakhat, H., Anwar, S., Mustafa Shah, G. and Rizwan Ashraf, M. (2015). Assessing Drinking water Quality in Punjab, Pakistan. Polish Journal of Environmental Studies, 24 (6): 2597-2606.

[18] Khan S, Cao Q, Zheng YM, Huang YZ, Zhu YG. (2008). Health risks of heavy metals in contaminated soils and food crops irrigated with wastewater in Beijing, China. Environmental Pollution, 152: 686-692.

[19] Wang, X., Sato, T., Xing, B. and Toa, S. (2005). Health risks of heavy metals to the general public in Tianjin, China via consumption of vegetables and fish. Science of Total Environment, 350: 28-37.

[20] Arora, M., Kiran, B., Rani, S., Rani, A., Kaur, B. and Mittal, N. (2008). Heavy metal accumulation in vegetables irrigated with water from different sources. Food Chemistry, 111: 811815.

[21] Rattan, R. K., Datta, S. P., Chhonkar, P. K., Suribabu, K. and Sing, A. K. (2005). Long-term impact of irrigation with sewage effluent on heavy metal content in soil, crops and ground water-a case study. Agricultural Journal Ecosystem and Environment, 109: 310-322.

[22] Gupta, N., Khan, D. K. and Santra, S. C. (2012). Heavy metal accumulation in vegetables grown in a long-term wastewaterirrigated agricultural land of tropical India. Environmental Monitory Assessment, 184: 6673-6682.

[23] Udosen, E. D., Offiong, N. O. and Alade, I. G. (2014). Human health risk assessment of trace metals due to dietary intake of some edible fish species collected from Enyong Creek, Itu, Nigeria. A paper presented at the $37^{\text {th }}$ international conference of chemical society of Nigeria held at Uyo Nigeria, 7-13 September.

[24] USEPA IRIS (United States Environmental Protection Agency, Integrated Risk Information System) (2006). $<$ http://www.epa.gov/iris/subst S $>$. Accessed 26/11/2012.

[25] USEPA (2001). Risk assessment guidance for superfund. Volume III. Process for conducting probabilistic risk assessment (Part A). United State environmental protection agency, available at www.epa.gov/superfund/RAGS3A/index.html. Accessed on 29th June, 2014.

[26] Swaileh, K. M., Hussein, R. M. and Abu-Elhaj, S. (2004). Assessment of heavy metal contamination in roadside surface soil and vegetation from West Bank. Archives of Environmental Contamination and Toxicology, 47: 23-30.

[27] Tegegne, W. A. (2015). Assessment of some heavy metals concentration in selected cereals collected from local markets of Ambo city, Ethiopia, Journal of Cereals and Oilseeds, 6 (2): 8-13.

[28] WHO (World Health Organization) (2001). Food additives and Contaminants, Joint FAO/WHO Standards Programme; ALINORM 01/02 A. pp 1-289.

[29] Chronopoulos, J., Haidouti, C., Chronopoulou-Sereli, A. and Massas, I. (1997). Variation in plant and soil lead and cadmium content in urban parks in Athens, Greece. Science Total Environment, 196: 91-98.

[30] Reuter, D. J. and Robinson, J. B. (1997). Plant analysis: an interpretation manual. (CSIRO Publishing: Australia).

[31] Saraf, A. and Samant, A. (2013). Evaluation of some minerals and trace elements in Achyranthes aspera linn. International Jounal Pharmaceutical Science, 3 (3): 229-233.

[32] Udosen, E. D., Benson, N. U., Essien, J. P. and Ebong, G. A. (2006). Relation between aqua-regia extractable heavy metals in soil and Manihot utilissima within a municipal Dumpsite. International Journal Soil of Sciences, 1: 27-32.

[33] Yusuf, K. A. and Osibanjo, O. (2006). Trace metals in water and sediments from Ologe Lagoon, Southwestern Nigeria Pakistan Journal of Science Industrial Research, 49: 88-96.

[34] Catharine Ross, A., Caballero, B., Cousins, R. J., Tucker, K. L. and Thomas R. Z. (2012): Modern Nutrition in Health and Disease / Edition 11, Publisher: Lippincott Williams \& Wilkins, ISBN-13: 9781605474618 pp. 3-6. 